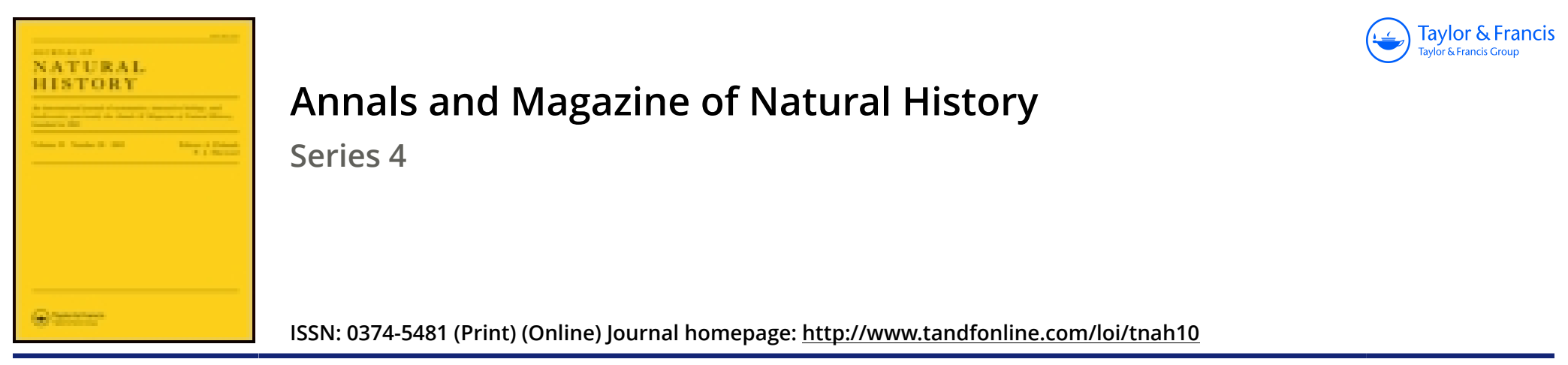

\title{
XLIX.-Description of a remarkable new pheasant from Borneo
}

\section{R. Bowdler Sharpe F.L.S. F.Z.S.}

To cite this article: R. Bowdler Sharpe F.L.S. F.Z.S. (1874) XLIX.—Description of a remarkable new pheasant from Borneo, Annals and Magazine of Natural History, 14:83, 373-374, DOI: 10.1080/00222937408680989

To link to this article: http://dx.doi.org/10.1080/00222937408680989

$$
\text { Published online: } 13 \text { Oct } 2009 .
$$

Submit your article to this journal $\sqsubset$

Џ Article views: 3

Q View related articles ๘ 
XLIX.-Description of a remarkable new Pheasant from Borneo. By R. Bowdler Sharpe, F.L.S., F.Z.S., \&c., Senior Assistant, Zoological Department, British Museum.

THE subject of the present notice will rival the remarkable discoveries of pheasants for which Mr. Swinhoe and Père David have been noted during the last few years, and will be a fit companion for Calophasis, Tetraophasis, and the other beautiful new genera which have lately enriched the family Phasianida. I have no hesitation in referring the bird just received by the Museum to a totally new and distinct genus, which I shall call Lobiophasis, on account of the long pendent lobes which ornament the sides of the throat. The metallic plumage allies it to no other genus in particular, though it approaches Euplocamus more than any pheasant in the form of the tail and arrangement of the plumage; but it is distinguished from this genus by its bare head, which reminds one of Numida. The tail is quite peculiar, all the outer feathers having stiffened shafts, devoid of web for some distance. Like Calophasis, this pheasant seems to be a mixture of several genera hurled into one form; but I consider the following short diagnosis sufficient to distinguish it:-

\section{LoBIOPHASIS, gen. $\mathrm{n}$.}

Of the general form of Euplocamus; but distinguished by the metallic endings to the dorsal and breast-feathers, and especially by the bare head, which is ornamented on each side of the throat by long pendent wattles. The type is

\section{Lobiophasis Bulweri, sp. n.}

Above brown, all the feathers terminally margined with metallic purple, of a harsh texture ; the neck-hackles similarly coloured; but here, owing to the individual plumes being divided, the general appearance of the metallic colouring is more spotted than on the back and upper tail-coverts, where the terminal metallic margins produce a somewhat barred appearance; wing-coverts uniform with the back, and having the same metallic spots; quills light brown, the outer primary with a pale whity-brown margin; the secondaries darker, and the innermost terminally margined with the same metallie colour as the back; lower back and rump-feathers uniform with rest of back, but the greater upper tail-coverts white, like the whole of the tail; head bare, with a large horn or wattle on each side of the occiput, and with a long pendent wattle on each side of the throat; round the hind neck a 
collar of dull maroon, all the feathers obscurely margined with metallic purple; chest also dull maroon, similarly obscured by purplish margins, which become broader and more distinct on the breast, which is black like the rest of the under surface, the metallic margins disappearing on the flanks and abdomen; under wing-coverts also dull brown, like the inner margin of the wing. Total length 28 inches, wing 11.5 , tail 16.5 , tarsus $3 \cdot 4$, pendent lobes $1 \cdot 25$.

Hab. Mountains of Lanos, Northern Borneo.

The unique specimen from which the above description has been taken has been presented to the Trustees of the British Museum by His Excellency H. E. Bulwer, C.M.G., Governor of Labuan. The wattles and ornaments on the face are stated to have been bright ultramarine in life.

\section{MISCELLANEOUS.}

Notes on the Varieties of the Western-American Weasels. By Dr. J. E. Gray, F.R.S. \&c.

The British Museum has lately received several specimens of these animals. They show the rariation in colour and markings that occur in the same species and in specimens from the same locality.

\section{Mustela brasiliensis.}

There are specimens from Veragua, Guatemala, and Costa Rica, which generally bave a white spot on the forehead between the eyes, and an oblique white streak from the back of the orbit to the front and underside of the ears; these spots and streaks vary in breadth. One specimen, from Veragua, has the head blackish brown, and with only a very indistinct white spot in front of the ears; and another, from Columbia, has only the small white spot on the forehead just between the eyes, and none on the side of the head. In another, large one, from Costa Rica, the head is entirely blackish, without any white spot or streak whatever. The specimens vary in the width of the yellow on the abdomen. In general the underpart of the thighs is yellow; but in one from Costa Rica the yellow part of the abdomen is narrow, and the whole underpart of the thighs is dark brown.

None of the specimens with the abdomen and the inner side of the thighs yellow has the yellow spot on the front upper margin of the thigh as represented in Taczanowski's figure of Mustela maerura from Central Peru (P. Z. S. 1874, pl. xlviii.), which is otherwise very like a variety of Mustela brasiliensis; and as the quantity of yellow seems to vary in the specimens of that species, it may be only an individual variety. There is a specimen of this species from Mexico which is 